ks. Janusz Lemański

\title{
Żydzi w oczach ewangelisty Mateusza
}

Jak zauważa Papieska Komisja Biblijna w swoim nowym dokumencie Naród żydowski i jego Święte Pisma w Biblii chrześcijańskiej: „, stosunki między pierwszą ewangelią a światem żydowskim są bardzo bliskie. Wiele szczegółów wskazuje tu na wielką znajomość Pism, tradycji i mentalności środowiska żydowskiego". Aby zrozumieć ten najbardziej semicki, pośród pism Nowego Testamentu, charakter Ewangelii Mateuszowej, trzeba najpierw odpowiedzieć sobie na trzy podstawowe pytania: Kto, do kogo i w jakiej sytuacji kieruje pismo, które określamy mianem Ewangelii według św. Mateusza?

\section{Środowisko i czas powstania Ewangelii Mateuszowej}

Odnośnie do środowiska, w którym powstała Ewangelia według św. Mateusza, panuje sensus communis we współczesnej biblistyce. Była nim Syria. To tam znajdowała się liczna diaspora żydowska, o czym wspomina już Józef Flawiusz (Wojna Żydowska 7, 43nn). Znamienny jest również fakt, że Mt 4, 24 w tzw. Sammelbericht wymienia ten region na pierwszym miejscu. Adresaci pisma wydają się nie znać już zbyt dobrze języka hebrajskiego, a Stary Testament cytowany jest według tłumaczenia Septuaginty. Wyraźny jest też istniejący już rozdział pomiędzy Kościołem a Synagogą, obie grupy religijne wydają się jednak pozostawać ze sobą w jakimś kontakcie. Czas powstania Ewangelii nie wydaje się wybiegać poniżej roku 70 po Chrystusie. Wyraźna wzmianka o zniszczeniu Jerozolimy w Mt 22, 7 wydaje się potwierdzać tę tezę. Kościół, do którego autor adresuje swoje pismo, wyrósł z judaizmu, choć dostrzega już swoją odrębność. Dobra znajomość tradycji żydowskiej to z jednej strony znak świadomości swoich korzeni i obecności w gminie wielu judeo-chrześcijan² ${ }^{2}$ jak również

${ }^{1}$ PAPIESKa Komisja Biblijna, Naród żydowski i jego Święte Pisma w Biblii chrześcijańskiej, Kielce 2002, s. 136.

${ }^{2}$ Por. aktualność szabatu Mt 12, 1-14; 24, 20; podatek na świątynię Mt 17, 24-27. Problem tego ostatniego tekstu w związku ze wspomnianym przekonaniem o powstaniu Ewangelii po roku 70, gdy świątynia była już zburzona, jest jeszcze przedmiotem ciągłej dyskusji. 
świadectwo bliskiej obecności wspólnoty synagogalnej, z którą doszło już do pierwszych zatargów na tle religijnym. Tożsamość tego młodego Kościoła ulega stopniowej ewolucji. Z jednej strony Mateusz stwierdza, że należy się strzec kwasu faryzeuszy i saduceuszy (Mt 16, 11-12), a z drugiej, iż należy ich słuchać ze względu na to, że zasiedli na katedrze Mojżesza, choć czynów ich nie poleca naśladować (Mt 23, 2-3).

\section{Autor}

Autor mógł być, jak chcą niektórzy egzegeci, przedstawicielem liberalnej, hellenistyczno-judaistycznej wspólnoty chrześcijańskiej. Z jednej strony bowiem nie widzi przeszkody w obecności nieobrzezanych w swojej gminie (Mt 28, 19), z drugiej jednak nie wydaje się być na tyle liberalny, by odrzucić Prawo (Mt 5, 17-18). Ten stosunek wobec Prawa jest u Mateusza dość złożony. Jezus nie przyszedł znieść Prawa, ale jak sam mówi, aby je wypełnić (Mt 5,17). Problem wydaje się jednak leżeć w podejściu do jego interpretacji i do samej praktyki w jego stosowaniu, jak uwydatnia to polemiczny charakter choćby takich tekstów, jak Mt 5 i 23. Możliwe więc, że wspólnota, do której pisze autor, ma w swoim gronie równie wielu Żydów, jak i świeżo nawróconych pogan. Współczesne opinie odnośnie do pochodzenia autora reprezentują dwie różne opcje. Jedna przyjmuje judeo-chrześcijańskie pochodzenie ewangelisty, a druga widzi w nim pogańskiego konwertytę. R. E. Brown uważa, że anonimowy ewangelista jest pochodzenia pogańskiego, i ten pogląd uznaje za dominujący wśród najważniejszych, jak to określa, komentatorów tego Pisma ${ }^{3}$. Trudno jednak zgodzić się z takim podsumowaniem dyskusji, zważywszy, że takie nazwiska jak Gnilka, Luz, Roloff, Hagner czy Schweizer nie należą do marginalnych postaci w dziedzinie egzegezy, a ci właśnie autorzy opowiadają się za judeo-chrześcijańskim pochodzeniem autora pierwszej Ewangelii. Bardziej ostrożna wydaje się więc opinia U. Schnelle ${ }^{4}$, który uważa kwestię za jeszcze nierozstrzygniętą ostatecznie we współczesnej egzegezie. Za żydowskim pochodzeniem autora wydają się przemawiać takie fakty, jak: (1) pozytywne spojrzenie na Prawo starego przymierza (Mt 5, 17-20; 23, 3a. 36); (2) charakterystyczne dla tej Ewangelii tzw. formuły wypełnienia znamionujące, że autor postrzega opowiadane przez siebie wydarzenia jako wypełnienie oczekiwań mesjańskich (mamy tu ponad 60 cytatów i szereg aluzji, które pozwalają sądzić, że głoszone nadejście Królestwa Bożego jest w oczach ewangelisty ostateczną odpowiedzią na te oczekiwania); (3) wyraźna prefe-

\footnotetext{
${ }^{3}$ Por. R. E. Brown, An Introduction to the New Testament, New York 1997, s. 210.

${ }^{4}$ Por. U. Schnelle, Einleitung in das Neue Testament, Göttingen 19962, s. 259-260.
} 
rencja próbująca ograniczyć zadania misyjne do ewangelizacji Izraela, które dopiero w ostatnim rozdziale znamionuje wyraźne otwarcie się na uniwersalizm (Mt 10, 5-6; 15, 24); (4) wspólnota Mateuszowa zachowuje jeszcze szabat (Mt 24, 20) i żyje w kontakcie z gminą żydowską, choć wyraźne są już znaki pogłębiającego się podziału; (5) wreszcie typologia Mojżesz-Jezus (Mt 2,13nn; 4, 1n; 5, 1) oraz stylizacja nauczania Jezusa na pięć wielkich mów, które stanowią wyraźną aluzję do Pięcioksięgu.

Za pogańskim pochodzeniem autora z kolei przemawia to, że Mateusz: (1) czyni aluzje do stopniowego otwierania się gminy na uniwersalizm zbawczy (Mt 28, 18-20; 8, 11n; 10, 18; 12, 18-21; 13, 38a; 21, 43-45; 22, 1-14; 24, $14 ; 25,32 ; 26,13)$, co sugeruje, że pomimo wspomnianych wyżej preferencji praktykowano jednak w niej misję wśród pogan; (2) odrzuca rytualizm Prawa żydowskiego (Mt 15, 11. 20b; 23, 25b) i krytykuje jego formalizm (antytezy Mt 5, 21-48); (3) wywyższa Jezusa nad Mojżesza, co w starożytnym judaizmie stanowi precedens; (4) polemizuje z kazuistyka faryzejską (Mt 5, 20; 6, 1nn; 9, 9nn; 12, 1nn. 9nn; 15, 1nn; 19, 1nn; 23, 1nn); (5) unika arameizmów (Mk 1, 13/Mt 4, 2; Mk 5, 41/Mt 9, 25; Mk 7, 34/Mt 15, 30; Mk 7, 11/Mt 15, 5). Wspólnota Mateuszowa ma więc już własną tożsamość i żyje w wyraźnym rozdziale z gminą żydowską. Jak zauważają autorzy dokumentu Papieskiej Komisji Biblijnej, ewangelista nie mówi już, że Jezus nauczał „w synagogach”,

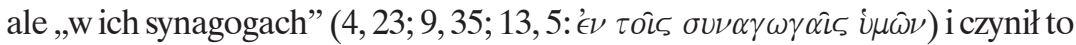

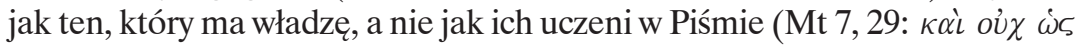
oi $\gamma \rho \alpha \mu \mu \alpha \tau \epsilon i \varsigma \alpha \dot{v} \tau \hat{\omega} \nu)$. Odrzucenie Izraela, pojmowanego w sensie etnicznym, jest od dawna dla tej chrześcijańskiej gminy faktem (Mt 8, 11n; 21, 43; 22, 9). Można zatem wnioskować, że sytuacja wspólnoty Mateuszowej zdradza wyraźnie cechy odrębności wobec synagogi. Przytoczone jednak wcześniej elementy wskazują na to, że autor, nawet jeśli przyjąć, iż jest chrześcijaninem pochodzenia pogańskiego, prezentuje doskonałą znajomość żydowskiego Prawa, zwyczajów i zakłada ją również u swoich czytelników. Co więcej, stara się w oparciu o tę wiedzę dać przesłanie pociechy w obliczu minionych i nadchodzących, jak zakłada, konfliktów z synagogą żydowską.

\section{Żydzi a problem zbawienia}

W piśmie Mateusza odbija się bardzo wyraźnie narastające napięcie pomiędzy młodym Kościołem a faryzejskim judaizmem. Po katastrofie pierwszego powstania żydowskiego, a więc po roku 70, kiedy zostaje zburzona świątynia i frakcja saduceuszy traci swoje znaczenie, to właśnie faryzeusze przejmą dominującą rolę w kształtowaniu się poglądów i opcji w społeczności żydowskiej. To właśnie ta frakcja, przewodnicząca zgromadzeniu na 
wybrzeżu palestyńskim, da początek ideowo nowej społeczności żydowskiej, która uznana zostanie przez władze rzymskie za oficjalnych rzeczników spraw żydowskich. W miejscowości Jamnia (Jamne) ${ }^{5}$ diaspora żydowska pod ich przywództwem, około roku 85 po Chr., wyda specjalny dekret znany jako Birkat hamminim ${ }^{6}$, wyłączający chrześcijan z liturgii synagogalnej. To początek definitywnego rozdziału Kościoła i judaizmu, choć ten uwydatnił się już wcześniej w wielu lokalnych konfliktach obu społeczności. Ewangelista wyraźnie zaznacza niektóre polemiczne aspekty wynikające z dyskusji pomiędzy obiema wspólnotami. Można tu wspomnieć rodowód Jezusa uzasadniający jego pochodzenie dyskredytowane jako nielegalne przez przywódców gminy żydowskiej czy apologia zmartwychwstania negowanego przez oponentów Kościoła rozpowszechniających pogłoski o oszustwie czy wręcz wykradzeniu ciała przez uczniów, czego ślad znajdujemy na końcu Ewangelii Mateuszowej $(28,12-15)$. Ten podział nie jest jeszcze jednak na tyle mocny, aby przeszkodzić w preferencyjnej opcji misyjnej wobec Żydów, co zaznacza się w mowie misyjnej Jezusa w czasie posłania dwunastu: „Nie idźcie do pogan i nie wstępujcie do żadnego miasta samarytańskiego! Idźcie raczej do owiec, które poginęły z domu Izraela” (Mt 10, 5-6) czy w surowej odpowiedzi udzielonej przez Jezusa kobiecie kananejskiej: „Niedobrze jest zabrać chleb dzieciom, a rzucić psom" (Mt 15, 24). Praktyka jednak wskazuje na wyraźne otwieranie się misji Kościoła na świat pogański; w Ewangelii dostrzegamy liczne tego dowody: imiona pogańskich niewiast, które odegrały ważną rolę w historii zbawienia (Rut i Rachab Mt 1,5), opowiadanie o magach (Mt 2, 1-12) i setniku z Kafarnaum (Mt 8, 5-13), historia kananejskiej kobiety (Mt 15, 21-28), przypowieści o przewrotnych rolnikach (Mt 21, 33-44) i uczcie królewskiej (Mt 22, 1-10), wyznanie rzymskiego żołnierza pod krzyżem (Mt 27, 54) czy wreszcie deklaracje o potrzebie uniwersalnej ewangelizacji wyrażone pod koniec Ewangelii (Mt 24, 14; 28, 19). To napięcie pomiędzy partykularyzmem i uniwersalizmem wydaje się, jak podkreśla Hagner, odzwierciedlać narastające napięcie na linii Żydzi-Kościół ${ }^{7}$. Jak ostateczne ostrzeżenie brzmią groźby skierowane wobec miast Galilei, w których Jezus zapowiada, że łatwiej będzie w dniu sądu pogańskim miastom Sodomie i Gomorze, Tyrowi i Sydonowi (Mt 11, 20-24). Współczesnych sobie żydowskich oponentów Jezus nazywa „złym i przewrotnym plemieniem” (Mt 12, 45; por. 13, 10-15). Jedynie u Mateusza znajdujemy dramatyczne słowa wypowie-

\footnotetext{
${ }^{5}$ Por. J. P. Lewis, Jamnia (Jabneh), Council of, [w:] ABD III, s. 634-637.

${ }^{6}$ Por. W. Horbury, The Benediction of the Minim and Early Christian Controversy, „Journal of Theological Studies" 33 (1983), s. 19-61.

${ }^{7}$ Por. D. A. Hagner, Matthew 1-13, Dallas 1993, s. LXVI (Word Biblical Commentary, 33A).
} 
dziane przez cały lud: „krew Jego na nas i na nasze dzieci” (Mt 27, 25). Ta wyraźna polaryzacja religijna nie musi jednak oznaczać, że ten definitywny rozdział już nastąpił, a wspomniane pierwszeństwo misji wśród Żydów nie wyklucza ich spośród narodów ( $\tau \dot{\alpha}$ ' $€ \theta \nu \eta$ ), do których skierowana ma być teraz Ewangelia (por. Mt 28, 19 i 24, 9; 25, 32). Judeo-chrześcijanie z gminy Mateuszowej musieli wszak spotykać się ze swymi współbraćmi z synagogi i prowadzić z nimi dysputy. Dla członków ortodoksyjnej wspólnoty żydowskiej chrześcijanie jawią się już jednak jako heretycy. Judeo-chrześcijanie mogli się czuć w tej sytuacji wyłączeni i prześladowani, czego wyraz znajdujemy w wypowiedziach ewangelisty: „dlatego oto Ja posyłam do was proroków, mędrców i uczonych. Jednych z nich zabijecie i ukrzyżujecie; innych będziecie biczować w swych synagogach i przepędzać z miasta do miasta” (Mt 23, 34; por. 10, 17-23). Choć według Mateusza Jezus krytykuje styl praktyk pobożnościowych judaizmu i określa go jako hipokryzję (Mt 6, 1-18), a swoim żydowskim oponentom zapowiada: „Królestwo Boże będzie wam odebrane, a dane narodowi, który wyda jego owoce" (Mt 21, 43; por. 22, 8), to nie wydaje się w kontekście całej Ewangelii, aby chodziło tu o ostateczne odrzucenie dokonane na zawsze przez cały naród żydowski. Ewangelista ma przed oczami naznaczony dominacją partii faryzejskiej krąg oficjalnego judaizmu i to przeciwko niemu kieruje ostrze swej polemiki, której szczyt znajdujemy w rozdz. 23, gdzie przywódców właśnie odpowiedzialnych za naród nazywa winnymi piekła (w. 15), ślepymi i głupimi (w. 17), przewodnikami ślepymi, którzy przecedzają komara, a połykają wielbłąda (w. 24), pełnymi obłudy i nieprawości (w. 28), wężami i plemieniem żmijowym (w. 33) ${ }^{8}$. Nie jest to zatem przejaw tendencji antyjudaistycznych, lecz wyraz polemiki wewnątrz judaizmu. Według Mateusza wszak Jezus przyszedł, aby wybawić swój lud (Mt 1, 22) i ocalić owce, które poginęły z domu Izraela (Mt 15, 24; por. 10, 5-6). Sama polemika z rozdz. 23 kończy się smutnymi, ale pełnymi nadziei słowami „Nie ujrzycie Mnie odtąd, aż powiecie: Błogosławiony, który przychodzi w imię Pańskie" (Mt 23, 39). Warto zwrócić w końcu uwagę, że Jezus choć krytykował, to również spotykał się i przyjaźnił z faryzeuszami, (Łk 7, 36; 11, 37; 14, 1) $)^{9}$ Ich zdecydowanie negatywna ocena w wersji Mateuszowej może być zatem wyrazem napięć, jakie pojawiły się po roku 70, kiedy ta frakcja religijno-polityczna zdominowała i zaczęła reprezentować judaizm, a niechęć wobec chrześcijaństwa przybrała tendencję wzrastającą po wydaniu wspomnianego już dekretu z Jamne.

${ }^{8}$ Por. E. A. Russell, „Antisemitism” in the Gospel of Matthew, "Irish Biblical Studies” 8 (1986), s. 183-196.

${ }_{9}^{9}$ Por. R. Schnackenburg, Matthäusevangelium 1, 1 - 16, 20, t. 1, Würzburg 1985, s. 10-11 (Die Neue Echter Bibel. Kommentar zum Neuen Testament mit der Einheitsübersetzung, 1). 
Kościół, który reprezentuje ewangelista, stanowi zatem alternatywę dla faryzejskiego judaizmu. Synagoga pojęta instytucjonalnie stała się w oczach gminy Mateuszowej zbyteczna po odrzuceniu propozycji chrześcijańskiej. Dlatego Jezus mówi „w ich synagogach”, a świątynia, notabene już zburzona, określona jest przez Jezusa jako dom, który pozostanie pusty (por. Mt 23, 38). Kościół Mateusza z judeo-chrześcijańskiego staje się etnico-chrześcijańskim, a obietnice dane Izraelowi przechodzą teraz także na pogan (Mt 2, 1-13; 27, 54; 28, 16-20), a więc na tych, którzy rokują nadzieję, iż wydadzą owoce (Mt 21, 43; por. 8, 11-12) ${ }^{10}$. Wspominane już formuły wypełnienia (Mt 1, 22n; 2, 15. 17-18. 23; 4, 14-16; 8, 17; 12, 18-21 itd.) mają wykazać, że Jezus jest oczekiwanym Mesjaszem, kimś, kto reprezentuje autorytet wyższy niż Mojżesz ${ }^{11}$, a jednocześnie zadać kłam fałszywym opiniom i wątpliwościom Żydów wobec Jezusa. To fakt odrzucenia Mesjasza przez urzędowy, a więc faryzejski judaizm prowadzi u Mateusza do powstania Kościoła. Jak zaznacza H. Langkammer ${ }^{12}$, tylko Mateusz pośród synoptyków używa pojęcia $\epsilon \kappa \kappa \lambda \eta \sigma ' \alpha$, które oznacza dla niego wspólnotę uczniów realizujących przesłanie Jezusa ${ }^{13}$. Wspólnota ta z racji niewiary przywódców żydowskich i tych, którzy pozostają pod ich wpływem, otwiera się na pogan. Ewangelista jednak dzieli wyraźnie Izraela na dwie grupy: tłumy słuchające Jezusa (Mt 8,$27 ; 9,33 ; 15,31$ ) i klasę rządzącą, określaną zwykle (nawet jeśli w innych Ewangeliach nie jest jasne, kim są) jako faryzeusze $(3,7 ; 12,38)$, łącząc ich często z uczonymi w Piśmie (Mt 5, 20; 12, 38; 23, 2). Faryzeusze pojawiają się na kartach Ewangelii Mateuszowej znacznie częściej niż w innych pismach Nowego Testamentu. Jezus uznaje ich pobożność, choć wymaga od swoich uczniów jeszcze większej sprawiedliwości (Mt 5, 20). Zachęca do słuchania ich jako tych, którzy zasiedli na katedrze Mojżesza, ostrzega jednak swoich słuchaczy przed naśladowaniem ich czynów (Mt 23, 1-20). Spór wydaje się więc nie mieć jeszcze charakteru ściśle doktrynalnego, lecz dotyczyć przede wszystkim praxis. Rozdział doktrynalny jednak wydaje się stać już u wrót. To właśnie faryzeuszy, w wersji Mateuszowej, Rabbi z Nazaretu pyta, co sądzą o Mesjaszu (Mt 22, 41-45; por. Mk 12, 35; Łk 20, 41 = uczeni w Piśmie). Mateusz jako jedyny z ewangelistów wkłada w ich usta oskarżenie, że Jezus

${ }^{10}$ Por. O. Da Spinetoli, Matteo, Assisi 1993, s. 8.

${ }^{11}$ Por. A. WeIser, Theologie des Neuen Testaments II: Die Theologie der Evangelien, Stuttgart 1993, s. 87-90. 104-105 (Kohlhammer Studienbücher Theologie, 8). Na temat tych cytatów, określanych także jako „cytaty refleksyjne”, zob. H. LANGKAmmER, Teologia Nowego Testamentu, t. 1, Wrocław 1985, s. 149.

${ }^{12}$ Por. Tamże, s. 156.

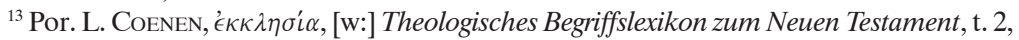
begründet durch E. Beyreuther, H. Bietenhard, und L. Coenen, Neukirchen 2000, s. 11361150, zwłaszcza 1145-1146. 
wyrzuca złe duchy mocą ich przywódcy (Mt 9, 34; 12, 24; por. Mk 3, 12 = uczeni w Piśmie; Łk 11, 15 = niektórzy z tłumu). Inaczej wreszcie niż Marka czy Łukasza, faryzeusze pojawiają się na pierwszym planie podczas pobytu Jezusa w Jerozolimie. To oni odrzucają przypowieść o przewrotnych rolnikach skierowaną (Mt 21, 45; por. Mk 12, 12; Łk 20, 19). Dla ewangelisty faryzeusze stali się zatem głównym przeciwnikiem Jezusa, dlatego są zawsze obecni i reprezentują opozycję wobec Mesjasza. Jak podkreśla G. Stemberger ${ }^{14}$, chodzi nie tyle o fakt historyczny, ile ucieleśnienie głównego przeciwnika wspólnoty chrześcijańskiej, reprezentującego oficjalnie judaizm w czasach, gdy powstaje Ewangelia Mateuszowa.

Ta polemiczna opcja wobec przywódców nie oznacza jednak odrzucenia poszczególnych członków narodu. Krytyka Izraela, może najwyraźniej widoczna w momencie procesu Jezusa przed Piłatem (Mt 27, 15-26), nie dotyczy z osobna każdego z jego członków. Mateusz wyraża tendencję dominującą wśród Żydów, ale nie wyłącza Izraela w ogóle spośród tych, do których ma być skierowana Ewangelia. Wszak pojęcie " $\theta \nu \circ \varsigma \mathrm{w}$ liczbie pojedynczej nie jest tożsame u Mateusza z określeniem pogan. Taki sens przybiera jedynie liczba mnoga tego rzeczownika ${ }^{15}$. Użycie tego terminu

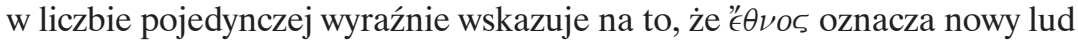
Boży, który zastępuje lud starego przymierza; jest to nowa wspólnota, w której nie więzy etniczno-narodowe, ale tożsamość religijna oparta na uznaniu Jezusa za Mesjasza odgrywać ma decydującą rolę. W tym sensie Mateusz zaznacza wyraźną różnicę między ’ $\theta \nu o \varsigma$ i $\lambda \alpha o ́ s$, które ma u niego zabarwienie pejoratywne ${ }^{16}$. Cały naród Izraela jest odpowiedzialny za odrzucenie i śmierć Mesjasza (Mt 27, 25) i w tym sensie utracił prawo do Królestwa Bożego. Będzie ono więc „od was zabrane i dane narodowi (' $\left.\epsilon \nu \circ \theta^{\prime}\right)$, który wyda jego owoce" (Mt 21, 43). Kryterium przynależności do nowego ludu Bożego, ,prawdziwego Izraela”, używając pojęcia ukutego przez Trillinga ${ }^{17}$, jest uznanie Jezusa za Mesjasza. Izrael zaś w sensie etniczno-narodowym utracił w oczach Mateusza wyłączne prawo do bycia ludem Bożym i tym samym dziedzicem Królestwa Bożego. Odrzucony Jezus bowiem jest dla Mateusza kimś więcej niż tylko prorokiem, jest Synem Bożym (Mt 2, 15; $3,17 ; 4,3 ; 8,29 ; 14,33 ; 16,16 ; 26,63 ; 27,43)$, a więc konsekwencją tego

${ }^{14}$ Por. G. Stemberger, Farisei, sadducei, esseni, Brescia 1993, s. 41-42 (Studi Biblici, 105).

${ }^{15}$ Por. J. Kudasiewicz, Teologia Ewangelii Synoptycznych, Lublin 1986, s. 84-85; H. BIETENHARD, "€ $\theta \nu 05$, [w:] Theologisches Begriffslexikon zum Neuen Testament, dz. cyt., t. 2, s. 18111815, zwłaszcza 1813.

${ }^{16}$ Por. J. Kudasiewicz, Ewangelie synoptyczne dzisiaj, Ząbki 1992, s. 211.

${ }^{17}$ Por. W. Trilling, Das wahre Israel. Studien zur Theologie des Mattäusevangeliums, Leipzig 1962. 
odrzucenia jest zwrot w biegu historii zbawienia ${ }^{18}$. Teraz to Kościół staje się dla Mateusza kontynuacją Izraela. Historia zbawienia, pomimo odrzucenia Mesjasza przez naród wybrany, toczy się dalej. Dla autora pierwszej Ewangelii obietnice Boże nie zostają unieważnione, zmienia się jedynie sposób ich realizacji. Dla Mateusza, jak dla św. Pawła, nacisk na potrzebę misji wśród Żydów wydaje się wyrażać nadzieję na to, że cały Izrael będzie nawrócony (por. Rz 11, 26 i Mt 23, 39). Wspominane już pojęcia ' $\epsilon \nu 0 \varsigma$

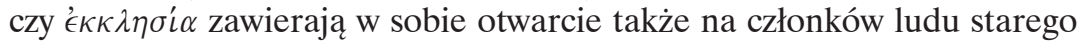
przymierza, oznaczają bowiem wspólnotę uczniów Jezusa, którzy akceptują Jego osobę i realizują Jego naukę. W ścisłym sensie oba terminy określają zarazem nową wspólnote, nowy Izrael, który stanowi, jak określi to Gnilka ${ }^{19}$, kritische Instanz wobec faryzejskiej formy judaizmu. Opowiadanie o magach przybyłych do Jerozolimy w poszukiwaniu Mesjasza, którzy są tam źle widziani (Mt 2,3), krytyka łatwowierności, że wystarczy mieć Abrahama za ojca, aby być pewnym zbawienia, wyrażona przez Jana Chrzciciela (Mt 3, 9), wiara setnika rzymskiego niespotykana w Izraelu (Mt 8, 10-12), sąd 12 apostołów nad pokoleniami Izraela (Mt 19, 28), protest Jezusa w świątyni znamionujący jego krytyczne stanowisko wobec sprawowanych tam rytuałów ofiarniczych (Mt 21, 12-14; por. 15, 8-9), odpowiedzialność za śmierć Jezusa spadająca na cały naród (Mt 27,25) i dyskutowana już ostra krytyka przywódców tego narodu (Mt 2, 4; 21, 23; 26, 3. 47; 27, 1) oraz ich próby przeszkodzenia w tym, aby wieść o zmartwychwstaniu dotarła do ludu (Mt 27, 62-64) - wszystko to razem znamionuje krytyczne stanowisko wobec starego ludu przymierza, który po katastrofie, jakim był upadek pierwszego powstania antyrzymskiego, skupił się wokół partii faryzeuszy i kształtował swoją tożsamość religijną według ich doktryny. W nowym rozumieniu jednak tego ludu problem kontynuacji dzieła zbawienia zostaje przezwyciężony. Dostęp pogan do obietnic danych Abrahamowi i całemu narodowi Izraela to skutek odmowy ze strony narodu wybranego. Jak zaznacza cytowany już dokument Papieskiej Komisji Biblijnej ${ }^{20}$, Jezus nie podkreśla jednak, że Królestwo Boże będzie odebrane narodowi wybranemu i dane innemu narodowi, lecz temu narodowi, który wyda jego owoce (Mt 21, 43). Jak pozwala sądzić kontekst całej Ewangelii, ten naród - kontynuuje dalej wspomniany dokument - będzie ustanowiony pod władzą dwunastu, zwłaszcza św. Piotra (Mt 16, 18), a apostołowie ci to przecież Żydzi.

${ }^{18}$ Por. J. KudAsiewicz, Ewangelie, dz. cyt., s. 214-215.

${ }^{19}$ J. GNILKA, Das Matthäusevangelium, Teil 2: Kommentar zu Kap. 14, 1 - 28, 20, Freiburg 1988, s. 544 (Herders theologischer Kommentar zum Neuen Testament, 1).

${ }^{20}$ Por. PAPIESKa KomisJa Biblijna, Naród żydowski i jego Święte Pisma w Biblii chrześcijańskiej, dz. cyt., s. 139. 


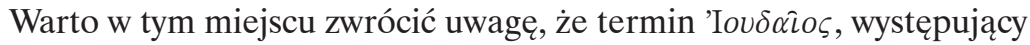
195 razy w Nowym Testamencie, tylko 19 razy pojawia się u synoptyków, z tego jedynie pięć razy u Mateusza ${ }^{21}$. W czterech wypadkach $(2,2 ; 27,11$.

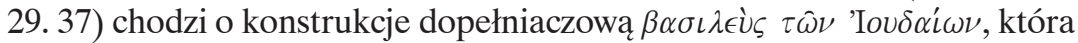
pojawia się w opiniach pogan: magów $(2,2)$, Piłata $(27,11)$, żołnierzy $(27$, 29) i jako oficjalny napis rzymskiego trybunału na krzyżu Jezusa $(27,37)$.

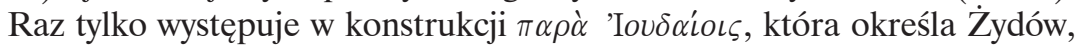
jako społeczność $(28,15)$, pośród której rozeszły się fałszywe pogłoski o wykradzeniu ciała Jezusa przez uczniów, ale inspiratorzy tego fałszerstwa są tu określeni jako arcykapłani i starsi (por. 28, 11-14). Ta ostrożność w użyciu tego określenia jest znamienna zwłaszcza w konfrontacji z Ewangelią Janową, znacznie późniejszą czasowo w stosunku do synoptyków.

Sumując powyższą analizę można zatem stwierdzić, że spojrzenie Mateusza Ewangelisty na naród żydowski i jego przywódców odzwierciedla narastające napięcie pomiędzy rozdzielającymi się synagogą i Kościołem, ale ukazuje także ciągłość historio-zbawczą obu wspólnot. Kościół wyrasta z obietnic starego przymierza i je wypełnia, a według Mateusza jest w nim miejsce dla wszystkich, którzy uznają Jezusa Chrystusa za Mesjasza, a więc także dla Żydów. Ponieważ synagoga reprezentowana przez faryzeuszy i innych przywódców narodu odrzuciła Jezusa jako Mesjasza, rolę nowej wspólnoty przymierza przejął Kościół, otwarty na wszystkich tych, którzy zdolni są wydać owoce Królestwa Bożego. Żydzi stanowią dla Mateusza i jego wspólnoty tych, których zwykliśmy dzisiaj za Janem Pawłem II określać jako „starszych braci w wierze”. Ewangelista nie tylko widzi dla nich miejsce w swojej gminie, ale uznaje ich prawo do pierwszeństwa w odbiorze Ewangelii, a winą za opóźnienie w przyjęciu wiary w Mesjasza obarcza przywódców narodu. Dostrzega jednak również odpowiedzialność tego narodu za śmierć Jezusa, jak i konsekwencje tego aktu, które spadają na cały Izrael. Drogę wyjścia widzi w nowym, eklezjalnym rozumieniu narodu wybranego, do którego w pierwszym rzędzie zaproszeni są Żydzi.

Koszalin

KS. JANUSZ LEMAŃSKI

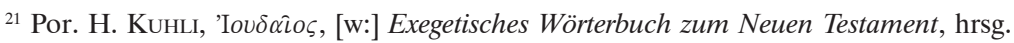
von H. Balz, G. Schneider, Stuttgart 1992², s. 472-482, zwłaszcza 476. 


\section{Riassunto}

Gli Ebrei nel vangelo secondo Matteo

Il modo di vedere gli Ebrei nel vangelo secondo Matteo è ben diverso da quello degli altri scritti del NT. Questa differenza emerge da uno specifico contesto ambientale e storico nel quale nasce l'opera di Matteo. Si tratta di un tempo in cui giudaismo viene sottoposto ad un'influenza della dottrina farisaica, la quale crea delle tensioni con la giovane Chiesa cristiana. Le divergenze sono la conseguenza dell'esclusione dei seguaci di Christo dalla sinagoga e del modo di comprendere il concetto stesso del popolo eletto. Secondo Matteo il concetto della comunità eletta da Dio non è basato sui legami etnico-nazionali, ma sulla relazione con Christo e con la sua opera salvifica. In tal modo viene pian piano superato il problema della presenza dei pagani nelle communità cristiane, come anche si conserva la priorità degli Ebrei nell'opera di salvezza, i quali non vengono esclusi da questo piano di Dio. 